\title{
RECENT DEVELOPMENTS ON THE DECIPHERMENT OF THE KHITAN SMALL SCRIPT*
}

\author{
ÁKOS BERTALAN APATÓCZKY - BÉLA KEMPF \\ 1. Károli University Budapest, Institute of Oriental Languages and Cultures \\ H-1088 Budapest, Reviczky u. 4., Hungary \\ e-mail: aab@azsiaport.hu \\ 2. University of Szeged, Klebelsberg Library, \\ H-6722 Szeged, Ady tér 10., Hungary \\ bkempf@bibl.u-szeged.hu
}

The authors review the past century of Khitan studies in Hungary and introduce the latest achievements in this field in China, the country that has become the centre of academic scrutiny for the decipherment of Khitan script in recent decades. Arranged in a chronologic order for the first time, an exhaustive list of the main known Khitan Small Script monuments is also included, followed by a selected bibliography of essential pieces on Khitan studies.

Key words: Khitan studies, Khitan Small Script, history of writing, decipherment of the Khitan Script, Para-Mongolic, Liao dynasty.

Ever since the publication of Louis Kervyn's articles (1923a, 1923b) ${ }^{1}$ about the discovery of Khitan ${ }^{2}$ language inscriptions, the decipherment of the scripts of the founders of the Liao dynasty has been in the foreground of Asian studies. The past almost hundred years of their study have seen climaxes and low points, but much to the de-

${ }^{*}$ The authors wish to express their gratitude to Professors András Róna-Tas and Mária Ivanics for making their visits to China possible, Professors Wu Yingzhe, Sun Bojun, Nie Hongyin, Bayartu, Yao Kecheng, Sechenbaatar for their invaluable help and advice during the visit and last but not least to Ms. Peng Daruhan, Mr. Jiruhe and Mr. Manduhu for their keen and tireless assistance.

${ }^{1}$ As Daniel Kane pointed out in his overview of Khitan studies (2009b), Kervyn was lucky enough to be at the right place at the right time when the findings he described were unearthed. The scholar, however, who made the first steps in the scholarly processing of these findings was Joseph Mullie (1922). A century earlier eighteen Khitan words with mostly doubtful readings and erroneously offered cognates were published in the famous Asia Polyglotta by Julius Klaproth (1823, pp. 294-295).

${ }^{2}$ There is an ongoing informal debate among scholars which English orthographic form of this ethnonym should be used in academia. Some vote for Kitan, others for Khitan and yet others for the pinyin Qidan. All these forms can be justified on different grounds; we are using here the Khitan form that, used in English orthography, probably stands closest to the assumed phonologic manifestation of the word. 
light of the philologists of the 21st century, the scrutiny of texts found earlier and in the recent decade has taken an ascending course. Khitan studies have come a long way from a time when the mere identification of the language behind the script was not a trivial task, through stages when the Khitan Small Script was thought to be related to Uighur script ${ }^{3}$ and scholars had only scattered information on the language with glosses embedded in Chinese works. During the first fifty years of research quite a large number of smaller discoveries were made by mostly Japanese, Russian and Chinese scholars, whose enumeration would reach far beyond the limits of this paper. The "Great leap forward" in this field in the 1970s by groups of Chinese researchers, hallmarked by the names of Professors Chingeltei and Liu Fengzhu, led to the first actual emendations retrieved from Khitan Small Script. Khitan data and corpus have been growing continuously until the present day, and in the past decades more and more studies have come to light with a goal to give a linguistic analysis to them. The amount of partially or nearly completely deciphered texts have indeed reached a critical mass, allowing experts to begin a more profound investigation of the language itself, and thus we have now theoretical conclusions, some of them more convincing than others, on the phonology, morphology and syntax of Khitan. With a number of recent works like that of Shimunek (2007), Kane (2009a), Wu-Janhunen (2010), Vovin (2011), Janhunen (2012), Zajcev (2011), Róna-Tas (2016a, 2016b) summarising our knowledge on the topic and the history of research, as well as contributing much to the "cracking" of the Khitan enigma, we now have a much more comprehensive view about Khitan language and writing than even a couple of decades ago.

This situation certainly encourages scholars to once again be preoccupied with the reading attempts of the extant data that have been put aside for some time. This trend is also accelerated by the turning up of newly discovered pieces of Khitan literacy sometimes pregnant with debates about the originality of some, but even counterfeited items - some of them produced with real craftsmanship - may be of value if they are handled with care and set serving the greater cause of academic knowledge.

Hungarian scholarship has traditionally been interested in and contributing to various fields of East-Asian philology, with a clear focus on, inter alia, historical linguistic research of the languages of the steppe area what is now belonging to Northern China and Southern Mongolia. At the dawn of the scholarly Khitan studies Professor Ligeti had summarised the contemporary knowledge and speculations on Khitan people and language in $1927^{4}$ and he also reported about the initial phases of the archaeological discoveries of Kervyn he got familiar with during his expeditions to the republican China between 1928 and 1931 (Ligeti 1933). During his long and fruitful academic activity Ligeti had always kept an eye on Khitan studies and from time to time returned to the topic (Ligeti 1950-1951, 1955, 1959, 1960, 1961, 1970). His disciples György Kara and András Róna-Tas have also contributed to the understanding of Khitan script and language. Kara's articles (1975, 1977, 1987, 1988, 2000,

${ }^{3}$ The identification of the two Khitan scripts was only done in the middle of the 1960s by Jin (1962) and Toyoda (1964).

${ }^{4}$ That time, due to a misinterpreted sentence of the Liao shi, Khitan Small Script was thought to be identical with Uighur script and this opinion is reflected in the work of Ligeti (1927). 
2005) helped taking a position to ascertain the Mongolic nature of Khitan. In 1996 he introduced the then accepted standpoints about Khitan literacy for the general public (Kara 1996). Róna-Tas (1999) in his inaugural lecture before the Hungarian Academy of Sciences analysed the parallels of the Khitan and the Hungarian social structures in the process of their settling down in the 10th century, later he idenitified a Khitan word of Tibetan origin (Róna-Tas 2004). His latest papers (Róna-Tas 2016a, 2016b) are providing new insights into the characteristics of the dotted and not dotted forms, the Khitan numerals as well as those of the etymology of the ethnonym "Khitan".

With a solid record like that it was an evident endeavour to establish a moreor-less steady body in Hungary for the investigation of Khitan documents promoted by Professor András Róna-Tas. According to the plan, an independent research group of invited experts working on a voluntary basis will be set up under the aegis of the University of Szeged to concentrate on the collection, documentation and conservation of the data, providing access to them for researchers and making the synergy of their extensive expertise exploitable. For practical reasons, due to the differences in the specific characteristics of Khitan Large and Small Scripts described by Janhunen (2012, pp. 108-109), the Khitan Large Script is excluded from the scope of investigation as of now, and the research is mainly concentrated on Khitan Small Script.

As a first step towards the realisation of this plan, a temporary group has been formed of linguists (Sinologists, Mongolists, Turkologists and general linguists) to fulfil the purpose of a preparatory project, in which phase all the available data and specific literature are gathered. To facilitate this effort, the group has set up ties with the Centre for Mongolian Studies at the Inner Mongolia University, probably the largest institution in the world whose scholars are engaged with Khitan studies and which has the latest possible information about recent archaeological findings. In December 2015 the authors of this report visited the colleagues in Beijing and Huhehaote to exchange views on the current issues in the field, making photocopies of inscription rubbings, as well as to collect the most important Chinese publications issued during the past decade. Professors Sun Bojun and Nie Hongyin kindly introduced us to the collection of Khitan rubbings at the Institute of Ethnology and Anthropology of the Chinese Academy of Social Sciences (中国社会科学院民族学与人类学研究所). Although during the past few years the institute's main interest turned towards another difficult case, Tangut script namely, their impact on modern Khitan Studies should definitely be mentioned. In Huhehaote we could get an even more comprehensive insight into the frontline of the current accomplishments in this field. Under the leadership of Professor Wu Yingzhe, the pace of the emergence of new results in Khitan Studies has accelerated. The first-hand processing of the newly found Khitan texts and fragments made the Center for Mongolian Studies of Inner Mongolia University a leading authority in the decipherment of Khitan Small Script (henceforth abbreviated as KSS). A conspicuous observation we had a chance to make concerned the surprisingly young age of the scholars involved in this research, strengthening our conviction that the productive work they are doing is done by an apparently energetic and well prepared academic staff. 
As a follow up to our first visit was our participation in the work of the First International Symposium on Ancient Scripts of Northern Nationalities (首届北方民 族古文字研究国际学术研讨会) in December 2016 hosted by the Inner Mongolia University. This event was organised to commemorate the inauguration of the similarly named institution established to research the above-mentioned scripts. Some sixty scholars from around the world gathered for the symposium the main topic of which was the scrutiny of Khitan inscriptions with some intruiguing new thougths and suggestions on the reading of some sources.

Following our fruitful visits, in this paper we would like to offer a short summary of the Chinese achievements made after 2010, as the previously mentioned works contain detailed descriptions of those published before that year. ${ }^{5}$

In $2010 \mathrm{Wu}$ Yingzhe 吴英喆 co-authored a book with Juha Janhunen dedicated to the critical edition of two previously found epigraphic texts, the Xiao Dilu and the Yelü Xiangwen inscriptions ( $\mathrm{Wu}-$ Janhunen 2010). This was the first time when Khitan texts were subject to a comprehensive analysis in the form of a critical edition. In the same year $\mathrm{Wu}$ Yingzhe published an article on the same text together with Baoyindeligen 宝音德力根 and Jiruhe 吉如何的: 《矢于新发现的几件契丹文墓志》[About several recently discovered Khitan epitaphs and previously published Khitan materials]. The authors give a detailed description of the epitaphs in Nie-Sun (2010, pp. 399-403). ${ }^{6}$

Liu Fengzhu 刘凤翥 in his article《契丹小字〈耶律宗教墓志铭〉考释》 [A philological study on Yelü Zongjiao's Khitan Small Script epitaph] (Wenshi 文史 2010/4) provided a reinterpretation of the Yelü Zongjiao 耶律宗教 epitaph.

Using the Jurchen data Sun Bojun (2010) 孙伯君 in her article 《契丹小字解 读新探》[A new attempt at reading the Khitan Small Script] tried to reinterpret sound values and the grammatical role of some original KSS characters in the Langjun inscription.

In $2011 \mathrm{Wu}$ Yingzhe issued an article 《契丹小字〈迭刺部〉考释》[A textual study on the tribal name Diela in the Khitan Small Script] (Wu 2011a) in which he discussed topics of the representation of the character 部 'tribe' in KSS, combining it with statements on the sound value system of the newly found Khitan Diela 迭剌 epitaph text, as well as on its contents. Speaking of the latter he argued that the 伏 今

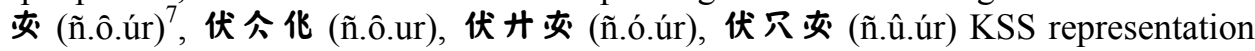

${ }^{5}$ The outline of this introductory part was first sketched with the kind assistance of Ms. Peng Daruhan at the Centre for Mongolian Studies, Inner Mongolia University. The list is far from being exhaustive, it rather reflects the opinion of Chinese scholars about what pieces of literature are thought to be important among them. The list was closed early 2015 .

${ }^{6}$ Liu Fengzhu, based on the names of the dynastic periods and that of the numerals in the texts, disputed the originality of these epigraphs in three articles (2011a, 2011b, 2011c), arguing that they were probably counterfeited. A reply from Wu Yingzhe (2011b) refuted Liu's arguments.

${ }^{7}$ Transcriptions for Khitan graphs if otherwise not indicated are according to $\mathrm{Wu}-$ Janhunen (2010), any alterations from them were either suggested by Mr. Jiruhe during our personal meeting in Höhhot in December 2016, for which help we are very thankful, or were the actual contributions of the cited work. 
of $b u$ 部 and $l u$ 路 should be read as niur, whereas the forms 伏今矢 (ñ.ô.li), 伏众

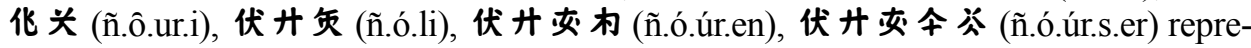
sent the plurals or additional elements to the plurals of $b u$ 部 and $l u$ 路. The forms 伏

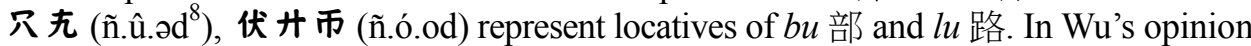
the glyph 小 'South' also present in the word 小列 for Diela 迭剌 as well as in 小杭 (SOUTH.en) 'compatriot' probably reflects linguistic relation, too. He further stated that 爷本カ (d.ra.qo) etc. equals to 小列 (SOUTH.hu), with a reading delag, and the separate forms of 小 'South' are 父亖 (de.le) 今云 (te.le) 令交布全 (t.ie.ra.d/t.ie.la.d),

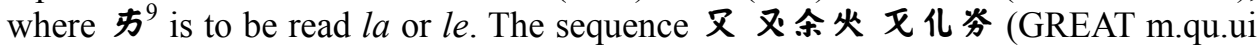
sh.ri.e) stands for 'Da Miegu Shilie' 大犎孤石烈. Another remarkable conclusion of this paper is that in KSS the phenomenon of consonant omission can be observed: 伏

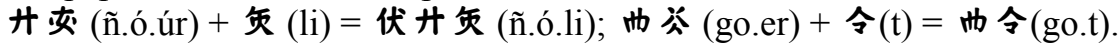

In the Master's thesis of Yirigui (2011)《契丹小字<耶律副部署墓志铭>与契丹大 字<耶律祺墓志铭>比较研究》 [Comparative study of the Khitan Small Script Epitaph of Deputy Administrator Yelü and the Khitan Large Script Epitaph of Yelü Qi], the author made a deeper analysis of the vowel attachment, the possessive case and of the grammatical gender in Khitan.

In his monograph《谜田耕耘一契丹小字解读续》[Thorough processing of a riddle - continuing the decipherment of Khitan Small Script], Ji Shi (2012) 即实 has cleared up the meaning of the following KSS words and expressions: 炎䒓友 (ng.iau.u), 亦本 (sh.ün.en), 'Yao and Shun 堯舜 (legendary sage leaders; a sage person)’, 角丸 (ca.au), 火岀 (x.iú) 'Chao and $X u$ 巢許 (legendary hermits; a hermit)', 头 (i), 全关 (s.i) ' $Y i$ and $Q i$ 夷齊 (legendary princes, sons of the Guzhu 孤竹 king)', 金炎 (s.ï iú) ' $Z i$ Y $u$ 子舆 (legendary official of the Spring and Autumn period)', 八及友勺 (dau.u jï.gu) 'Dao Zhi 盗跖 (legendary bandit of the Spring and Autumn

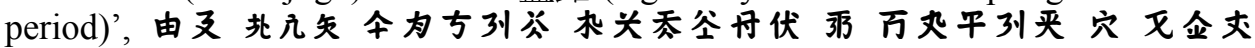
(320.úr us.(u)g.de s.a.al hu.er ci.i.is d.b.eñ jau y.au.ul.hu.an.nai sh.em.qú) 'Filial piety

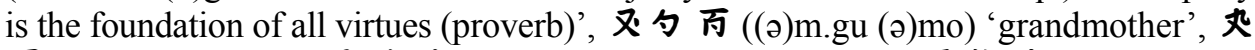
万 (au (ə)mo) 'aunt', 九任丸 (g.mu au) 'husband's parents', 忝爸列 (is.d.hu) 'nine

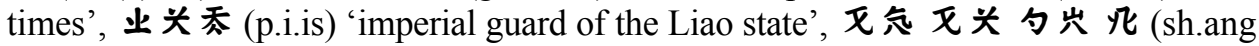
sh.i gu.iú shï<尚食局使) 'officer of the imperial food service'.

Wu Yingzhe (2012a) in his book《契丹小字新発見資料釈読問題》[Interpretation problems of the newly-discovered Khitan Small Script materials] investigated the following texts: Yelü Jue muzhiming 耶律玦墓誌銘, Xiao Huilian muzhiming 蕭 回璉墓誌銘, Xiao Hudujin muzhiming 蕭胡睹堇墓誌銘, Yelü Pusuli muzhibeiming 耶律蒲速里墓誌碑銘. According to his textual criticism, Xiao Hudujin 蕭胡睹堇 was the elder brother of the owner of the Xiao Huilian 蕭回璉 tomb, while Xiao Hudujin 蕭胡暏堇 and Xiao Huilian 蕭回璉 were the uncles of Xiao Dilu 蕭敵魯. This book was the first to present the full text of the Yelü Jue muzhiming 耶律玦墓誌銘, the Xiao Huilian muzhiming 蕭回璉墓誌銘, the Xiao Hudujin muzhiming 蕭胡睹

\footnotetext{
${ }^{8}$ For the last graph see Aisin Gioro (2012).

9 The transcription of this graph is not given in $\mathrm{Wu}-\mathrm{Janhunen}(2010)$.
} 
堇墓誌銘 and the Yelü Pusuli muzhibeiming 耶律蒲速里墓誌碑銘 inscriptions along with their decipherment, the photocopies of the rubbings, as well as an index of the vocabulary. At the same time he carried out an exhaustive philological study on clan history. He read 月尺公 (372.û.er) as a personal name Shu Lulie 術魯列, and hence reconstructed the pronunciation of $\mathrm{A}$ as shul, furthermore, he explained some personal names, too: 全号巫 (s.iau qa) as Xiao He 蕭何, 孔令夾亚 (ja.ang liáng) as

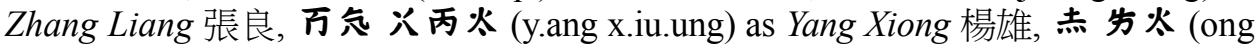
t.ung) as Wang Tong 王通.

The same year Wu Yingzhe (2012b) issued an article《契丹文典故<人生七 十古来稀>》 [A study on a literary quotation in Khitan Script: “A man seldom lives to be seventy years old"]. In this article he argues that the literary quotation

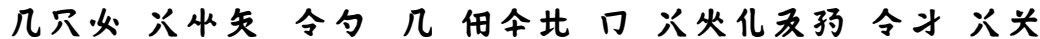

ku.û.un x.(ə)l.de t(u).gu ku BORN.sui.el SEVENTY x.ui.ri.u.ji t.ia xi

in the Epitaph of Yelü Taishi was most probably taken from the famous Tang poet $D u$ Fu's poem 曲江二首 'On the Qujiang River', and stands for the verse rensheng qishi gu lai xi 人生七十古來稀 'A man seldom lives to be seventy years old'.

In $2013 \mathrm{Wu}$ Yingzhe and Tang Jun 唐均 edited a collection of Khitan studies in the 8th issue of Acta Linguistica et Litteraturaria Sinica Occidentalia (Huaxi yuwen xuekan 华西语文学刊) (Wu-Tang 2013), containing more than 30 articles on Khitan language and script, Liao and Khitan history, archaeology and culture, as well as interviews with scholars who dedicated their careers to the research of the Liao Khitan cultural history, reviews of books and a sum-up of the 1st and 2nd International Seminar of Khitan Script and Related Academic Fields.

Liu Pujiang 刘浦江 and Kang Peng 康鹏 edited a reference book 契丹小字词汇索 引 [An index of the Khitan Small Script lexicon] (Liu-Kang 2014) including the material of $33 \mathrm{KSS}$ inscriptions and 16 fragmentary material.

Liu Fengzhu's article from 2014《契丹小字<故耶律氏铭石>考释》 [Philological examination of the Gu Yelü shi 故耶律氏 inscription in Khitan Small Script] provided a deeper analysis of the text.

In the article 《内蒙古大学所藏契丹字文献资料》[Khitan Script materials preserved by the Inner Mongolia University] Gaowa (2014) 高娃 gives an introduction to the KSS inscriptions conserved by the Inner Mongolia University. Discussing some details, she argues that Shuyinu 淑儀奴, the author of the Xiao Dilu 蕭敵魯 epitaph, was not the son-in-law of the tomb owner's nephew, but probably the husband of the owner's daughter called 丸化分与 (mó.ur.û.én). She also compares the 4th line

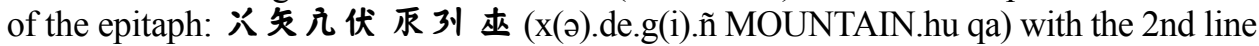
天矢九伏由列來籴夹 (x(ə).de.g(i)ñ qar.hu qa.ha.an) of Yelü Jue 耶律玦, and comes to the conclusion that 乍列 (MOUNTAIN.hu) and 由 列 (qar.hu) are alternative names of Hendejin khan 痕德堇可汗, and with regard to the 15th line of the Epitaph of General Xianwu 顯武將軍 (that is the Xiao Jushi 蕭居士 epitaph), 古及 (horu) is speculated to be an alternative writing method for 由 3 ( 
This, according to the paper, implies a connection between 古及 (horu) and the origin of the Middle Mongolian haran 'people' and qara 'black'. The graphs 古 and 由 may have been pronunced as har or hara. The substitute graph 承 may also have had a similar har or hara reading (Gaowa 2014, pp. 151-152).

In their article 《辽<高玄圭墓志>考释》[A philological investigation of the eulogy of Gao Xuangui of Liao] Kang Peng 康鹏, Zuo Lijun 左利军 and Wei Congcong 魏㙂聪 (2014) stipulate that the Gaosh $i$ 高氏 family was moved to the court at the time of its establishment at the Liao Zhongjing 中京. Another statement of this article is that Xingyunshan 興雲山 in the Liao epitaphs equals to Qingyunshan 慶雲山 in the Liaoshi. About the genealogy of the Gaoshi family they ascertain that the father of Gao Xuangui 高玄圭 was Qing Ting 慶廷, his mother was Zhao Shi 趙氏, and they had four children: Shi Lin 士林, Liu Shi 留士, Yu Ge 雨歌 and Shi Ning 士寧, as well as five grandsons Bing Wen 秉溫, Bing Liang 秉良, Bing Gong 秉恭, Bing Jian 秉儉, Bing Rang 秉讓 and four granddaughters.

\section{APPENDIX}

The currently available corpus of KSS inscriptions consists of the following main scripts and fragments. The fact that seventeen years ago there were only 21 pieces known (Liu Fengzhu 1999, pp. 160-165) shows that the occurrence of archaeological findings of Khitan material has accelerated since then.

\section{A Chronologic List of Extant Khitan Small Script Monuments ${ }^{10}$}

\section{Abbreviations}

$\begin{array}{ll}\text { K } & \text { Kane (2009a) } \\ \text { KSS } & \text { Khitan Small Script } \\ \text { L } & \text { Literature } \\ \text { LIU } & \text { Liu Fengzhu (1999) } \\ \text { WJ } & \text { Wu-Janhunen (2010) } \\ \text { WU } & \text { Wu (2012a) }\end{array}$

1053 | Zongjiao | 宗教 | Epitaph of Yelü Zongjiao | Da Qidanguo Guangling jun wang muzhimingji | 大契丹國廣陵郡王墓誌銘記.

Discovered: Gaoqi Village, Beining, Liaoning (遼寧省北寧市鮑家鄉高起村) 1991. Kept in Beining Cultural Relics Office (北寧市文物管理處) $\mid 33$ lines, 935 characters. L: Lu-Xin-Wu (1993), Yan (1993), Liu-Zhou-Zhao-Zhu (1995) [K 32; WJ 11; WU 12]

${ }^{10}$ Detailed descriptions of the items are not given here as they are readily available in the cited sources. We found it useful, however, to present a chronologic enumeration of the known sources to facilitate further research. All data are according either to LIU (Liu Fengzhu 1999), K (Kane 2009a), WJ (Wu-Janhunen 2010), or WU (Wu 2012a). 
1055 | Xingzong | 興宗 | Eulogy for Emperor Xingzong | Xingzong huangdi aice | 興 宗皇帝哀冊.

Discovered: Mausoleum of Emperor Xingzong, Barin Right Banner, Inner Mongolia, (内蒙古赤峰市巴林右旗白塔子) June 1922.

The original stele is still in the Yongxing tomb (永興陵), buried in an unknown location at the Imperial Mausoleum (遼慶陵). Only a handwritten copy is available | 36 lines, 861 characters.

L: Kervyn (1923a; 1923b), Mullie (1933), Jin Yufu (1934) [K 23; WJ 1; WU 01]

1057 | Xiao Linggong | 蕭令公 | Damaged epitaph of Xiao Linggong | Xiao Linggong muzhiming canshi $\mid$ 蕭令公墓誌銘殘石.

Discovered near Xishan Village, Qinghemen district, Fuxin, Liaoning (遼寧省阜新 市清河門區西山村) in 1950. Kept in Liaoning Provincial Museum (遼寧省博物館)| 32 lines, 594 characters.

L: Li Dingkui (1954), Li Wenxin (1954) [K 14; WJ 7; WU 06]

1068 | Tuguci | 圖古辭 | Epitaph of Xiao Tuguci | Xiao Tuguci muzhiming | 蕭圖古 辭墓誌銘.

Discovered in Fuxin Mongol Autonomous Prefecture, Taipingxiang dadaocun sijia zitun (阜新蒙古族自治縣太平鄉大道村四家子屯) in 2000. Kept in Liaoning Provincial Institute of Cultural Relics and Archaeology (遼寧省文物考古研究所) | 26 lines, 740 characters.

L: Liang (2003) [K 22; WJ 27; WU 22]

1071 | Yelü Jue | 耶律玦 | Epitaph for Yelü Jue (1014-1070) | Yelü Jue muzhiming | 耶律玦墓誌銘.

Time and place of discovery are unknown. Kept in Aohan Banner, Xinzhou Museum (敖漢旗, 新州博物館) | 46 lines, 2530 characters.

L: [WU 36]

1072 | Renxian | 仁先 | Epitaph of Yelü Renxian | Da Liao guo shang fu yu Yue Song wang muzhiming | 大遼國尚父於越宋王墓誌銘.

Discovered in Dongshan Village, Xiao tazi township, Beipiao prefecture, Liaoning (遼寧省北票縣小塔子鄉東山村) in 1983. Kept in Liaoning Provincial Institute of Cultural Relics and Archaeology (遼寧省文物考古研究所) | 70 lines, approx. 5000 characters.

L: Han (1991), Ji (1991) [K 16; WJ 10; WU 10]

1076 | Renyi | 仁呪恣 | Eulogy for Empress Renyi | Renyi huanghou aice | 仁呚皇后 哀冊.

Discovered together with the Xingzong inscription at the Mausoleum of Emperor Xingzong, Barin Right Banner, Inner Mongolia (内蒙古赤峰市巴林右旗白塔子) in June 1922. The original stele is still in the Yongxing tomb (永興陵), buried in an unknown location at the Imperial Mausoleum (遼慶陵). Only a handwritten copy is available | 32 lines, 575 characters.

L: Kervyn (1923a), Kervyn (1923b), Mullie (1933), Jin Yufu (1934) [K 17; WJ 2; WU 02] 
1078 Temei | 特每 | or | Hanshi | 韓氏 | Epitaph of Mme. Han, second wife of the imperial son-in-law Xiao Temei-Kuoge | Xiao Temei-Kuoge fuma di'er furen Han shi muzhiming | 蕭特每-䦚哥騳馬第二夫人韓氏墓誌銘.

Only rubbings extant (found in 2004) | 32 lines, 810 characters.

L: Liu Fengzhu (2005a) [K 21; WJ 32; WU 26]

1080 | Xiao Huilian | 蕭回璉 | Epitaph of Xiao Huilian Xiao Huilian muzhiming | 蕭 回璉墓誌銘.

Time and place of discovery are unknown, assumed place of origin is the vicinity of Taipingxiang, Fuxin Mongol Autonomous Prefecture (阜新蒙古族自治縣太平鄉). Kept in Imperial Examination Museum (北京科舉匾額博物館) | 3 lines, 14 characters (lid), 32 lines, 840 characters (text).

\section{L: [WU 38]}

1082 | Cite | 慈特 | or | Wuluben | 烏盧本 | Epitaph of Yelü Cite | Yelü Cite muzhiming/Yelü Wuluben muzhiming |耶律慈特墓誌銘 / 耶律烏盧本墓誌銘.

Discovered near Baiyinwendu sum, Ar Horchin Banner, Inner Mongolia (內蒙古赤 峰市阿魯科爾沁旗白音溫度蘇木) in 1997. Kept in Ar Horchin Banner Museum (阿魯科爾沁旗博物館) $\mid 2$ lines, 15 characters (lid), 28 lines, 915 characters (text).

L: Liu-Cong-Yu-Narangua (2006) [K2; WJ 23; WU 28]

1088 | Yongning | 永寧 | Damaged epitaph of Prince Yelü Yongning | Yelü Yongning langjun muzhiming canshi $\mid$ 耶律永寧郎君墓誌銘殘石.

Discovered near Wopu Village Zhengjia, Gongyingzi Township, Kharchin Banner, Inner Mongolia (內蒙古赤峰市喀喇沁旗公營子鄉鄭家窩鋪村) in 1995. Kept in the Museum of Kharchin Banner (喀喇沁旗博物館) $\mid 43$ lines, approx. 1060 words.

L: Zheng Xiaoguang (2002) [K 26 and $27^{11}$; WJ 16; WU 19]

1091 | Shizhong | 侍中 | Epitaph for Gu Shizhong (1015-1090) | Gu Shizhong muzhiming | 故侍中墓誌銘.

Time and place of discovery are unknown, acquired by Inner Mongolia University in 2009, kept in the Center for Mongolian Studies of Inner Mongolia University (蒙古 學學院) | 33 lines, 1700 characters.

\section{L: [WU 40]}

1091 | Hudujin | 胡睹堇 | Epitaph for Hudujin Shenmi or Xiao Hudujin (1041-1091) | Xiao Hudujin Shenmi muzhiming 蕭胡睹堇審密墓誌銘.

Time and place of discovery are unknown, assumed place of origin is the vicinity of Taipingxiang, Fuxin Mongol Autonomous Prefecture (阜新蒙古族自治縣太平鄉). Kept in the Khitan Museum, Chifeng, Barin Left Banner, Inner Mongolia (内蒙古赤 峰市巴林左旗契丹博物館) | 39 lines, approx. 1480 characters.

\section{L: [WU 35]}

\footnotetext{
${ }^{11}$ This single inscription is listed as two, namely Yelü Langjun canshi 耶律郎君殘石 and Yelü Yongning langjun muzhiming canshi 耶律永寧郎君墓誌銘殘石 in Kane (2009a).
} 
1091 | Xiangwen | 詳穏 | Epitaph for Yelü Xiangwen (1010-1091) | Yelü Xiangwen muzhi | 耶律詳穏墓誌.

Time and place of discovery are unknown, acquired by Inner Mongolia University in 2007, kept in the Center for Mongolian Studies of Inner Mongolia University (蒙古 學學院) | 39 lines, 1440 characters (front), 9 lines, 190 characters (back).

\section{L: [WU 34]}

1092 | Dilie | 迪烈 | Epitaph of Yelü Dilie | Nanzhanbuzhou Da Liao guo Gu Dilie wang muzhiwen | 南瞻部洲大遼國故迪烈王墓誌文.

Discovered near Gahaitu Township, Jarud Banner, Inner Mongolia (内蒙古扎魯特旗 嘎亥圖鎮) in 1995. Kept in Liao and Jin City Wall Museum, Beijing (北京遼金城垣 博物館) | 32 lines, approx. 1690 characters (front), 9 lines (lid).

L: Lu Yinghong - Zhou (2000), Bao Lianqun (2002) [K 4; WJ 20; WU 16]

$1094 \mid$ Zhixian | 智先 | Epitaph of Yelü Zhixian | Yelü Zhixian muzhiming | 耶律智先 墓誌銘.

Discovered at Dongshan Village, Xiaotazi township, Beipiao county, Liaoning province (遼寧省北票縣小塔子鄉東山村) in 1998. Kept in Beipiao Museum (北票市博 物館) | 27 lines, approx. 1000 characters.

L: Zhao Zhiwei-Bao (2001) [K 30; WJ 24; WU 18]

1095 | Yongqing (永清) | Epitaph of Princess Yongqing | Yongqing gongzhu muzhiming | 永清公主墓誌. (Also known as Xiao Taishan he Yongning gongzhu muzhiming 蕭太山和永清公主墓誌銘).

Discovered broken into two pieces near Songjialiang tun, Ahantu village, Pingandi township, Fuxin Mongol Autonomous Prefecture (阜新蒙古族自治縣平安地鄉阿漢 土村宋家梁屯) in 2003. Kept at the Fuxin Prefecture Cultural Relics Management Bureau (阜新蒙古族自治縣文物管理所) | 32 lines, approx. 1330 characters.

L: Yuan-Liu (2005) [K 28; WJ 30; WU 25]

1099 | Yelü Nu | 耶律奴 | Epitaph of Yelü Nu (1041-1098) | Yelü Nu muzhiming | 耶 律奴墓誌銘.

Discovered near Yaoyamen Village, Fuxin Mongol Autonomous Prefecture, Liaoning (阜新蒙古族自治縣大板鎮腰衙門村) in 1999. Kept in Fuxin City Museum (皁新 市博物館) | 48 lines (24 front, 24 back), approx. 1270 characters.

L: Shi-Yu (2001) [K 15; WJ 25; WU 17]

1099 | Wotelan | 斡特懶 | Epitaph for Prince Wotela (1073-1099), the grandson of Gu Shizhong | Yelü Wotelan langjun muzhiming | 耶律斡特懶朗君墓誌銘.

Time and place of discovery are unknown (only the inscription was found, whereabouts of the lid is unknown). Acquired by Inner Mongolia University in 2009, kept in the Center for Mongolian Studies of Inner Mongolia University (蒙古學學院) | 22 lines, approx. 1000 characters.

\section{L: [WU 41]}


$1100 \mid$ Hongyong | 弘用 | Epitaph of Yelü Hongyong (1054-1086) (also known as the Wurigentala Inscription - Epitaph of Yelü Hongbian) | Yelü Hongyong muzhiming | 耶律弘用墓誌銘.

Discovered at Wurigentala, Jarud Banner, Inner Mongolia (内蒙古通遼市扎魯特旗 烏日根塔拉農場) in 1996. Kept in Jarud Banner Cultural Relics Office (扎魯特旗文 物管理所) | 32 lines, 900 characters.

L: Chen - Yang (1999), Yang (2003), Liu Fengzhu-Qinggele (2003) [K 11; WJ 18; WU 15]

$1100 \mid$ Shilu | 室魯 | Epitaph of Shilu taishi $\mid$ Shilu taishi muzhi bei | 室魯太師墓誌 碑.

Discovered in Shuiquangou, Yihebei Village, Jarud Banner, Inner Mongolia (內蒙古 扎魯特旗伊和背鄉水泉溝) in 2000. Kept in the Liaozhongjing Museum of Ningcheng county (內蒙古寧城縣遼中京博物館) $\mid 2$ lines, 6 characters (back), 13 lines, 154 characters (inscription).

L: Liu Fengzhu-Dong (2007) [K 18; WJ 26; WU 29]

1101 | Taishi | 太師 | Epitaph for Yelü Taishi (1038-1101), the son of Yelü Xiangwen | Yelü Taishi muzhiming 耶律太師墓誌銘.

Time and place of discovery are unknown. Acquired by Inner Mongolia University in 2009, kept in the Center for Mongolian Studies of Inner Mongolia University (蒙古 學學院) | 26 lines, approx. 1040 characters.

\section{L: [WU 39]}

1101 | Yelü Han | 耶律韓 | Epitaph of Yelü (Han) Dilie (also written as Dilie 敵烈) | Yelü (Han) Dilie muzhiming | 耳阝律(韓)迪烈墓誌銘.

Discovered at Sifangcheng township, Barin Left Banner, Inner Mongolia (內蒙古 巴林左旗四方城鄉) in 1996. Kept in Liao Shangjing Museum (遼上京博物館) | 34 lines, approx. 1350 characters.

L: Tang Cailan-Liu-Kang (2002), Liu Fengzhu-Tang-Gaowa (2004) [K 10; WJ 19; WU 21]

1101 | Daozong | 道宗 | Eulogy for the Emperor Daozong | Daozong huangdi aice | 道宗皇帝哀冊.

Excavated in 1930 from the Yongfu tomb of the Imperial Mausoleum (遼慶陵, 永福 陵). Kept in the Liaoning Provincial Museum (遼寧省博物館) $\mid 6$ lines with 36 characters (lid) and 37 lines and approx. 1130 characters (stone).

L: Meng (1932), Wang Jingzu (1933), Jin Yufu (1934) [K 3; WJ 4; WU 04]

1101 | Xuanyi | 宣懿 | Eulogy for Empress Xuanyi | Xuanyi huanghou aice | 宣懿皇 后哀冊.

Excavated in 1930 from the Yongfu tomb of the Imperial Mausoleum (遼慶陵, 永福 陵). Kept in the Liaoning Provincial Museum (遼寧省博物館) $\mid 4$ lines with 16 characters (lid) and 30 lines and approx. 620 characters (stone).

L: Meng (1932), Wang Jingzu (1933), Luo (1933), Jin Yufu (1934) [K 25; WJ 5; WU 05] 
1102 | Fubushu | 副部署 | Epitaph of Deputy Administrator Yelü| Yelü fubushu muzhiming | 耶律副部署墓誌銘.

Discovered at Tsogt Mountain near Guriban Hushu Gacha, Han sumu, Ar Horchin Banner, Inner Mongolia (內蒙古阿魯科爾沁旗罕蘇木古日班呼碩嘎査, 朝克圖山) in 1996. Kept in the Inner Mongolia Museum, Huhehaote (呼和浩特市内蒙古博物 院) $\mid 27$ lines (lid) and 27 lines (stone), approx. 2000 characters.

L: Gai-Qi-Liu (2008) [K 5; WJ 17; WU 30]

1102 Diligu | 迪里姑 | Epitaph of Yelü Diligu (also known as the Epitaph of Yelü Gui 耶律貴, 1061-1102) | Yelü Diligu muzhiming | 耶律迪里姑墓誌銘.

Time and place of discovery are unknown. Acquired in 2002 and kept in Liao Shangjing Museum (遼上京博物館) | 31 lines, approx. 1020 characters.

L: Liu Fengzhu-Tang-Gaowa-Li (2006) [K 8; WJ 29; WU 27]

1105 | Xuguo | 許國 | Damaged epitaph of Prince Xu | Liaoguo xuwang muzhi canshi | 遼國許王墓誌殘石.

Discovered at Baitaigou village, Wofenggou township, Fuxin Mongol Autonomous Prefecture, Liaoning province (阜新蒙古族自治縣臥風溝鄉白台溝村) in 1975. Kept in Fuxin City Museum (阜新市博物館) $\mid 30$ lines on both the front and the back of the stone, and 4 lines of Khitan and five lines of Chinese script on the sides, approx. 2750 characters. Both the stone itself and the lid are corrupted.

L: Fuxin (1977), Ji (1996, pp. 139-179) [K 24; WJ 9; WU 08]

1105 | Pusuli | 蒲速里 | Epitaph of Yelü Pusuli | Yelü Pusuli muzhibeiming | 耶律蒲 速里墓誌碑銘.

Time and place of discovery, as well as the actual whereabouts of the inscription are unknown | 2 lines 15+11 characters (lid), 25 lines, approx. 800 characters.

L: [WU 37]

1107 | Liang guowang | 梁國王 | Epitaph for the Prince of Liang | Liang guowang muzhiming | 梁國王墓誌銘.

Discovered near Guan Mountain, Daba town, Fuxin Mongol Autonomous Prefecture, Liaoning province (阜新蒙古族自治縣大巴鎮関山) in 2001. Kept in Liaoning Provincial Institute of Cultural Relics and Archaeology. (遼寧省文物考古研究所) | Chinese characters on the surface of the lid, Khitan Small Script on the back: 29 lines, 1280 characters.

L: Han-Yoshimoto (2007), Wan-Han-Liu (2008) | [K 13; WJ 28; WU 31]

$1108 \mid$ Cishi | 刺史 | Epitaph of the Prefect of Zhuozhou (Also known as the Epitaph of the Prefect of Zezhou 澤州刺史墓誌) | Zhuozhou Cishi muzhi canshi | 溷州刺史 墓誌殘石.

Discovered in Sanshan township, Chifeng city, Barin Left Banner, Inner Mongolia (赤峰市巴林左旗三山鄉) in 1994. Kept in Liao Shangjing Museum (遼上京博物 館) | 26 lines, approx. 230 characters, top right of the inscription is missing due to damage to the stone.

L: Wang Weixiang (1999), Wang Ding (2004, pp. 226-310) [K 29; WJ 14; WU 14] 
1110 | Taishuzu | 太叔祖 | Eulogy for the Imperial Grand Uncle (Also known as the Huang taishuzu aice 皇太叔祖哀冊) $\mid$ Gu Taishuzu aice | 故太叔祖哀冊.

Discovered in the Western part of the Yongxing tomb (永興陵) of the Imperial Mausoleum (遼慶陵), Baitazi, Barin Right Banner, Inner Mongolia (巴林右旗白塔子) in 1997. Kept in Barin Right Banner Museum (巴林右旗博物館) 25 lines, approx. 795 characters.

L: Chengel-Liu (2003) [K 20; WJ 21, WU 23]

1110 | Song Wei | 宋魏 | Epitaph of the Imperial Consort of Song and Wei $\mid \mathrm{Gu}$ Song Wei Guo fei muzhiming | 故宋魏國妃墓誌銘.

Discovered together with the Taishuzu aice in the Western part of the Yongxing tomb (永興陵) of the Imperial Mausoleum (遼慶陵), Baitazi, Barin Right Banner, Inner Mongolia (巴林右旗白塔子) in 1997. Kept in Barin Right Banner Museum (巴林右 旗博物館) $\mid 24$ lines, 642 characters.

L: Liu Fengzhu-Qinggele (2003) [K 19; WJ 22, WU 24]

$1114 \mid$ Xiao Dilu | 蕭敵魯 $\mid$ Epitaph for Xiao Dilu $\mid$ Xiao Dilu muzhiming $\mid$ 蕭敵魯墓 誌銘.

Time and place of discovery are unknown, the assumed place of discovery, however, is the vicinity of Fuxin Mongol Autonomous Prefecture, Taipingxiang (阜新蒙古族 自治縣太平鄉附近挖掘). Acquired by Inner Mongolia University in 2007, kept in the Center for Mongolian Studies of Inner Mongolia University (蒙古學學院) | 25 lines and 580 characters (lid), 26 lines and 520 characters (stone).

\section{L: [WU 33]}

1115 | Gu Yelü | 故耶律) | Epitaph of the Late Mme. Yelü | Gu Yelü shi mingshi | 故耶律氏銘石.

Discovered in the Liao tomb of Maobulagou, Shanzuizi, Ongniud Banner, Chifeng City, Inner Mongolia (赤峰市翁牛特旗山嘴子毛布拉溝遼代墓) in 1962. Kept in the Chifeng City Museum (赤峰市博物館) $\mid 25$ lines, 695 characters.

L: Zhaowuda-Wengniute (1981), Liu Fengzhu-Yu (1981b) [K 7; WJ 8; WU 09]

$1134 \mid$ Langjun | 郎君 | Record of the Journey of the Younger Brother of the Emperor of the Great Jin Dynasty | Da Jin huang di dutong jinglüe langjun xingji 大金皇弟都 統經略郎君行記.

The only extant Khitan-Chinese bilingual inscription was engraved on a stele in front of the Tang Qianling tomb of Empress Wu Zetian of the Tang in Qian county, near Xi'an, Shaanxi province (陝西省乾縣唐乾陵) $\mid 5$ lines and 96 characters (Khitan text) and 6 lines and 108 characters (Chinese text).

L: Haneda (1925), Jin Yufu (1934) [K 12; WJ 3; WU 03]

1150 | Xiao Zhonggong | 蕭仲恭 | Epitaph of Xiao Zhonggong | Xiao Zhonggong muzhiming $\mid$ 蕭仲恭墓誌銘.

Discovered near the location of the later Yanzhangzi commune Zimu linzi village, Xinglong County, Hebei (河北省興隆縣閻杖子公社梓木林子村) in 1942. Kept by the Hebei Province Office of Cultural Relics (河北省保定市文物管理處) | 50 lines and 2490 characters (stone) and 3 lines and 9 characters (lid). 
L: Zheng Shaozong (1973), Liu Fengzhu-Yu (1981a), Kara (1975) [K 31; WJ 6; WU 07]

1170 | Zhenguo | 鎭國 | Epitaph of the Supreme General of Zhenguo (Also known as the Epitaph of the Defense Commissioner of Bozhou of the Jin Dynasty 金代博州防 禦使墓誌) | Zhenguo Shangjiangjun muzhiming | 鎭國上將軍墓誌銘.

Discovered in Laohugou Village, Xindi township, Aohan Banner, Chifeng city, Inner Mongolia (赤峰市敖漢旗新地鄉老虎溝村) in 1993. Kept in the Aohan Banner Museum 51 lines, approx. 1500 characters.

L: Zhu Zhimin (1995), Liu Pujiang (1999), Aisin Gioro (2007) [K 1; WJ 13; WU 13]

$1175 \mid$ Xiao Jushi | 蕭局使 ${ }^{12} \mid$ Epitaph of Xiao Jushi $\mid$ Xiao Jushi muzhiming | 蕭居 士墓誌銘.

Discovered near Songjialiang tun, Ahantu village, Pingandi township, Fuxin Mongol Autonomous Prefecture (阜新蒙古族自治縣平安地鄉阿漢土村宋家梁屯) in 2004. Kept at the Fuxin Prefecture Cultural Relics Management Bureau (阜新蒙古族自治 縣文物管理所) | 2 lines and 13 characters (lid) and 33 lines and approx. 1350 characters (stone).

[WU 32]

Unknown date:

- | Haitangshan | 海棠山 | Damaged epitaph found near Haitangshan | Haitangshan muzhi canshi | 海棠山墓誌殘石.

Discovered in Moya zaoxiang qun, Fuxin Mongol Autonomous Prefecture, Liaoning (阜新蒙古族自治縣大板摩崖造像群) in 1991. A large part of the stone is missing. Kept at the Fuxin Prefecture Cultural Relics Management Bureau (阜新蒙古族自治 縣文物管理所) | 13 lines, 300 characters.

L: Lü-Yuan (1992), Liu Fengzhu (1993a), Lü (1995) [K 9; WJ 12; WU 11]

- | Gaoshi | 高十 | Epitaph of Yelü (Han) Gaoshi | Han (Yelü) Gaoshi muzhiming | 韓 (耶律)高十墓誌銘.

Discovered in the Han family tombs at Baiyinhan Mountain, Baiyinwula township, Barin Left Banner (巴林左旗白音烏拉鄉白音罕山韓氏家族墓誌群) in 1995. The text of the inscription is incomplete and the lid has not been found $\mid 26$ lines, approx. 750 characters.

L: Liu Fengzhu (2002) [K 6; WJ 15; WU 20]

${ }^{12}$ In Wu (2012a) it was listed as 蕭居士, but he has changed the reading since then. 


\section{References and a Selected Bibliography on Khitan}

As the volume of scholarly works on Khitan has increased in the past hundred years, it is impossible - and unnecessary - to strive for a complete bibliography about the topic (hundreds of articles on it are issued yearly in China alone). It may be useful, however, to present here a selected list of the probably most important pieces of literature that have led us to our present understanding of the KSS and the language of the Khitan people.

Aisin Gioro, Ulhicun 爱新觉罗 (2007): Qidan xiaozi «Jindai Bozhou fangyushi muzhiming» muzhu fei Yila Woliduo - jianlun Jinchao chuqi wu “Nüzhen Guo" zhi guohao 契丹小字〈金代 博州防御使墓志铭〉墓主非移剌斡里朵 - 兼论金朝初期无“女真国”之国号 [The tomb owner of the epitaph of the Defense Commissioner of Bozhou of the Jin period in the Khitan Small Script was not Yila Woliduo, and the dynasty name "Nüzhen Guo" did not exist at the beginning of the Jin period]. Manyu yanjiu 满语研究 No. 1, pp. 72-78.

Aisin Gioro, Ulhicun [Yoshimoto, Chieko 吉本, 智慧子] (2012): Kittan koaza no onga suitei oyobi sōkan mondai 契丹小字の音価推定及び相関問題 [Reconstruction of the phonetic values of Khitan Small Scripts and concerning problems]. Ritsumeikan bungaku 立命館文学 No. 627 , pp. $157-129$.

Bai Guang 白光-Zhang Hanying 张汉英 (1994): Liaodai “Tan Shan” kao 辽代“炭山”考 [A study of Mount Tan of the Liao period]. Beifang wenwu 北方文物 No. 2, pp. 77-81.

Bao Lianqun 包联群 (2002): «Nan[zhan] Buzhou Daliao guo Gu Dilie wang muzhiwen» de buchong kaoshi〈南[瞻]部洲大辽国故迪烈王墓志文〉的补充考释 [A supplementary study of the epitaph of the Late Prince Dilie of the Great Liao]. Nei Menggu daxue xuebao (Zhexue shehui kexueban) 内蒙古大学学报(哲学社会科学版) No. 3, pp. 15-19.

Bao Yuzhu 寶玉柱 (2006): Qidan xiaozi ji qi tihuanzi yanjiu 契丹小字及其替換字研究 [Research on the Khitan Small Script character and its variants]. Nei Menggu daxue xuebao (Zhexue shehui kexueban) 内蒙古大学学报 (哲学社会科学版) No. 1, pp. 8-12.

Chen Naixiong 陈乃雄 (1987): Jin shinian lai woguo qidanzi yanjiu 近十年来我国契丹字研究 [Research on the Khitan script in our country over the past ten years]. Nei Menggu daxue xuebao (Zhexue shehui kexueban) 内蒙古大学学报 (哲学社会科学版) No. 3, pp. 105-133.

Chen Naixiong 陈乃雄 (1988): Qidanzi yanjiu shulüe 契丹字研究述略 [A brief survey of research on the Khitan script]. In: Eguchi, Paul Kazuhisa (ed.): Languages and History in East Asia. A Festschrift for Tatsuo Nishida on the Occasion of his 60th Birthday. Kyoto, Shokado, pp. 237-287.

Chen Naixiong 陈乃雄-Bao Lianqun 包聮群 (2005): Qidan xiaozi yanjiu Lunwen Xuanbian 契

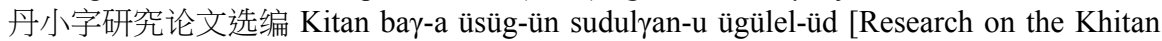
Small Script: a selection of papers]. Huhehaote, Nei Menggu Renmin chubanshe.

Chen Naixiong 陈乃雄 - Yang Jie 杨杰 (1999): Wurigentala Liaomu chutu de qidan xiaozi muzhiming kaoshi 乌日根塔拉辽墓出土的契丹小字墓志铭考释 [A study of the epitaph in the Khitan Small Script excavated from the Liao tomb at Wurigentala]. Xibei minzu yanjiu 西北民族研究 No. 2, pp. 72-88.

Chengel 清格勒-Liu Fengzhu 刘凤翥 (2003): Qidan xiaozi «Huangtai shuzu aicewen» kaoshi 契丹小字〈皇太叔祖哀册文〉考释 [A study of the Khitan Small Script eulogy for the imperial grand uncle]. Minzu yuwen 民族语文 No. 5, pp. 13-19.

E’erdunbate'er 额尔敦巴特尔 (1996): Jianlun qidan dazi he nüzhen wenzi de bijiao yanjiu 简论契 丹大字和女真文字的比较研究 [Comparative research on the Khitan Large and Jurchen scripts: a brief discussion]. Nei Menggu daxue xuebao (Zhexue shehui kexueban) 内蒙古大 学学报 (哲学社会科学版) No. 3, pp. 50-58. 
Fuxin xian wenhuaju wenwuzu 阜新县文化局文物组 (1977): Liaoning Fuxin xian Liao Xu wangmu qingli jianbao 辽宁阜新县辽许王墓清理简报 [A brief report on the inventory of the tomb of the Liao Prince $\mathrm{Xu}$ in Fuxin, Liaoning]. Wenwu ziliao congkan 文物资料丛刊 No. 1, pp. 84-87.

Gai Zhiyong 盖之庸 (2002): Neimenggu Liaodai shikewen yanjiu 内蒙古辽代石刻文研究 [Research on the stone inscriptions of the Liao Period in Inner Mongolia]. Huhehaote, Nei Menggu daxue chubanshe.

Gai Zhiyong 盖之庸-Qi Xiaoguang 齐晓光-Liu Fengzhu 刘凤埭 (2008): Qidan xiaozi «Yelü Fubushu muzhiming» kaoshi 契丹小字〈耶律副部署墓志铭〉考释 [A study of the epitaph of Deputy Administrator Yelü in the Khitan Small Script]. Nei Menggu wenwu kaogu 内蒙 古文物考古 No. 1, pp. 81-111.

Gao Lujia 高路加 (1988a): Qidan xiaozi fushu fuhao tansuo 契丹小字复数符号探索 [A study of the plural markers in the Khitan Small Script]. Nei Menggu daxue xuebao (Zhexue shehui kexueban) 内蒙古大学学报 (哲学社会科学版) No. 2, pp. 18-23.

Gao Lujia 高路加 (1988b): Qidan xingshi Yelü yinyi xintan 契丹姓氏耶律音义新探 [A new investigation into the pronunciation and meaning of the Khitan surname Yelü]. Nei Menggu daxue xuebao (Zhexue shehui kexueban) 内蒙古大学学报 (哲学社会科学版) No. 4, pp. 7082.

Gaowa 高娃 (2014): 内蒙古大学所藏契丹字文献资料 [Khitan Script materials preserved by the Inner Mongolia University]. Zhongyang Minzu Daxue xuebao (Zhexue shehui kexueban) 中 央民族大学学报 (哲学社会科学版) No. 4, pp. 150-153.

Guo Tiangang 郭添刚 - Cui Song 崔嵩 - Wang Yi 王义-Liu Fengzhu 刘凤青 (2009): Qidan xiaozi «Xiao Jushi muzhiming》 kaoshi 契丹小字〈萧居士墓志铭〉考释 [A study of the epitaph of Xiao Jushi in the Khitan Small Script]. Wenshi 文史 No. 1, pp. 227-256.

Han Baoxing 韩宝兴 (1991): Qidan xiaozi «Yelü Renxian muzhi» kaoshi 契丹小字〈耶律仁先墓 志〉考释 [A study of the epitaph of Yelü Renxian in the Khitan Small Script]. Nei Menggu daxue xuebao (Zhexue shehui kexueban) 内蒙古大学学报 (哲学社会科学版) No. 1, pp. $70-78$.

Han Shiming 韩世明 - Yoshimoto, Chieko [Aisin Gioro, Ulhicun] 吉本智慧子 (2007): Liang guo wang muzhi mingwen chushi 梁国王墓志铭文初释 [A first study of the epitaph of the Prince of Liang]. Minzu yanjiu 民族研究 No. 2, pp. 85-89.

Haneda Tōru 羽田亭 (1925): Kittan moji no shin shiryou 契丹文字の新資料 [New data on the Khitan script]. Shirin 史林 Vol. 10, No. 1, pp. 82-97.

Janhunen, Juha (2012): Khitan: Understanding the Language behind the Scripts. SCRIPTA No. 4, pp. $107-132$.

Ji Shi 即实 (1991): «Jiulin muzhi» jiaochaoben ji qita〈幻邻墓志〉校抄本及其它 [The edited copies of the epitaph of Jiulin and other matters]. Nei Menggu daxue xuebao (Zhexue shehui kexueban) 内蒙古大学学报 (哲学社会科学版) No. 1, pp. 79-106.

Ji Shi 即实 (1996): Milin Wenjing: Qidan xiaozi jiedu xincheng 谜林问径 - 契丹小字解读新程 [Seeking a path through a forest of riddles - A new stage in the decipherment of the Khitan Small Script]. Shenyang, Liaoning minzu chubanshe.

Ji Shi 即实 (2012): Mitian gengyun - qidan xiaozi jieduxu 谜田耕耘 - 契丹小字解读续 [Thorough processing of a riddle - Continuing the decipherment of Khitan Small Script]. Shenyang, Liaoning minzu chubanshe.

Jin Guangping 光平 (1962): Cong qidan da, xiaozi dao nüzhen da, xiaozi 从契丹大, 小字到女真 大，小字 [From the Khitan Large and Small Scripts to the Jurchen Large and Small Scripts]. Nei Menggu daxue xuebao 内蒙古大学学报 No. 2, pp. 9-14. 
Jin Yufu 金毓栊 (ed.) (1934): Liao Ling Shike Jilu 遼陵石刻集録 [Collection of inscriptions from the Liao tombs]. Fengtian, Guoli Fengtian Tushuguan.

Jiruhe 吉如何 - Wu Yingzhe 吴英喆 (2009): Qidan xiaozi yuanzi zixing guifan yu yuanzi zongbiao 契丹小字原字字形规范与原字总表 [The standardisation of the Khitan Small Script character forms and a general list of the characters]. Nei Menggu daxue xuebao (Zhexue shehui kexueban) 内蒙古大学学报 (哲学社会科学版) No. 3, pp. 127-132.

Kane, Daniel (2009a): The Kitan Language and Script. Leiden-Boston, Brill (Handbook of Oriental Studies / Handbuch der Orientalistik, Section Eight, Central Asia 19).

Kane, Daniel (2009b): Louis Kervyn, Joseph Mullie and the Beginnings of Khitan Studies. In: Rybatzki, Volker-Pozzi, Alessandra-Geier, Peter W.-Krueger, John R. (eds): The Early Mongols: Language, Culture and History. Studies in Honor of Igor de Rachewiltz on the Occasion of his 80th Birthday. Bloomington, Indiana, Indiana University, The Denis Sinor Institute for Inner Asian Studies (Indiana University Uralic and Altaic Series 173), pp. 7990.

Kang Peng 康鹏-Zuo Lijun 左利军-Wei Congcong 魏聪聪 (2014): Liao “Gao Xuangui muzhi” $k a o s h i$ 辽<高玄圭墓志>考释 [A philological investigation of the eulogy of Gao Xuangui of Liao]. Beifang wenwu 北方文物 No. 3, pp. 79-82.

Kara, György (1975): A propos de l'Inscription de 1150 en écriture khitane. Annales Universitatis Scientiarum Budapestinensis, Sectio Linguistica No. 6, pp. 163-167.

Kara, György (1977): Xyatan bičgiin xoyor togtolcoonii tuxai [About the two systems of Khitan script]. In: Luvsandendev, A. (ed.): Olon ulsiin mongolč erdemtnii III-r ix xural. II. Ulaanbaatar, BNMAU Olon ulsiin mongolč erdemtnii ix xurliin baingiin xoroo, pp. 86-89.

Kara, Görgy (1987): On the Khitan Writing Systems. Mongolian Studies Vol. 10, pp. 19-24.

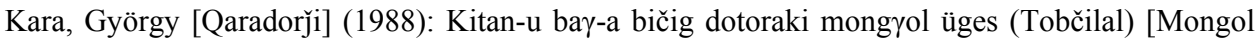

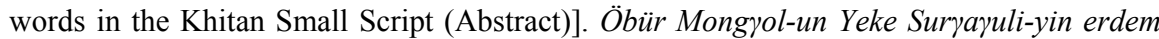
sinjilgen-ü sedkül No. 1, pp. 55-56.

Kara, György (1996): Siniform Scripts of Inner Asia. Kitan and Jurchin. In: Daniels, Peter T.Bright, William (eds): The World's Writing Systems. Oxford-New York, Oxford University Press, pp. $230-238$.

Kara, György (2000): Pre-Mongol and Mongol Writing. In: Asimov, M. S. - Bosworth, C. E. (eds): History of Civilization of Central Asia IV: The Age of Achievement: A.D. 750 to the End of the Fifteenth Century. Paris, UNESCO, pp. 335-337.

Kara, György (2005): Hit, hatalom és írás a mongol világban [Faith, power, and writing in the Mongol world]. In: Vizi E., Szilveszter (ed.): Székfoglalók a Magyar Tudományos Akadémián. 2001. Társadalomtudományok [Inaugural lectures before the Hungarian Academy of Sciences. 2001. Humanities]. Budapest, Magyar Tudományos Akadémia, pp. 43-57.

Kervyn, Louis (1923a): Le tombeau de l'empereur Tao-tsong (1101) - Une découverte intéressante. Bulletin Catholique de Pékin Vol. 10, pp. 237-243.

Kervyn, Louis (1923b): Le tombeau de l'empereur Tao-tsong des Leao, et les premières inscriptions. T'oung Pao Vol. 22, pp. 292-301.

Klaproth, Julius (1823): Asia polyglotta. Paris, Schubart.

Li Dingkui 厲鼎烓 (1954): Yixian chutu qidanwen muzhiming kaoshi 義縣出土契丹文墓誌銘 考釋 [A study of the Khitan epitaph excavated at Yixian]. Kaogu xuebao 考古學報 No. 8， pp. 203-211.

Li Wenxin 李文信 (1954): Yixian Qinghemen Liaomu fajue baogao 義縣清河門遼墓發掘報告 [Report on the discovery of a Liao tomb at Qinghemen, Yixian]. Kaogu xuebao 考古學報 No. 8, pp. 163-202. 
Liang Zhenjing 梁振晶 (2003): Fuxin Sijiazi Liaomu fajue jianbao 阜新四家子辽墓发掘简报 [A brief report on the excavation of the Liao tomb at Sijiazi, Fuxin]. Liaoning kaogu wenji 辽宁考古文集 pp. 121-130.

Ligeti, Lajos (1927): A kitaj nép és nyelv [The Khitan people and their language]. Magyar Nyelv Vol. 23, pp. 293-310.

Ligeti, Lajos (1933): Rapport préliminaire d'un voyage d'exploration fait en Mongolie Chinoise. 1928-1931. Budapest, Société Körösi-Csoma.

Ligeti, Lajos (1950-1951): Mots de civilisation de Haute Asie en transcription chinoise. AOH Vol. 1 , pp. $141-188$.

Ligeti, Lajos (1955): [R] G. D. Sanžeev, Sravnitel'naja grammatika mongol'skix jazykov. Tom 1. Moskva-Leningrad, Institut Jazykoznanija AN SSSR, 1953. Voprosy jazykoznanija No. 5, pp. $133-140$.

Ligeti, Lajos (1959): Les mots solons dans un ouvrage chinois des Ts'ing. $A O H$ Vol. 9, pp. $231-$ 272.

Ligeti, Lajos (1960): Les anciens éléments mongols dans le mandchou. $A O H$ Vol. 10, pp. 231-248.

Ligeti, Lajos (1961): A mandzsu nyelv régi mongol elemei [The older Mongolian elements of the Manchu language]. MTA Nyelv- és Irodalomtudományi Osztályának Közleményei Vol. 17, pp. $31-46$.

Ligeti, Lajos (1970): Le tabghatch, un dialecte de la langue sien-pi. In: Ligeti, Louis (ed.): Mongolian Studies. Budapest, Akadémiai Kiadó (Bibliotheca Orientalis Hungarica 14), pp. $265-$ 308.

Liu Fengzhu 刘凤䩮 (1981): Qidan dazi he xiaozi de qubie 契丹大字和小字的区别 [The difference between the Khitan Large and Small Scripts]. Neimenggu shehui kexue 内蒙古社会科学 No. 5, pp. 105-112.

Liu Fengzhu 刘凤泉 (1982): Qidan xiaozi zhong de ji nian kaoshi 契丹字中的纪年考释 [A study of the year notations in the Khitan Large Script]. Minzu yuwen 民族语文 No. 2, pp. 49-53.

Liu Fengzhu 刘凤翥 (1983): Qidan xiaozi jiedu zaitan 契丹小字解读再探 [The Khitan Small Script: a reinvestigation]. Kaogu xuebao 考古学报 No. 2, pp. 255-270.

Liu Fengzhu 刘凤翥 (1987a): Ruogan qidan xiaozi de jiedu 若干契丹小字的解读 [The decipherment of some Khitan Small Script characters]. Minzu yuwen 民族语文 No. 1, pp. 62-65.

Liu Fengzhu 劉鳳翥 (1987b): Qidan xiaozi jiedu santan 契丹小字解讀三探 [The Khitan Small Script: a third investigation]. In: Lianhe shuyuan sanshi zhounian jinian lunwenji 聯合書院 三十周年紀念論文集 [Memorial papers for the 30th anniversary of the United College, The Chinese University of Hong Kong]. Hong Kong, Xianggang Zhongwen daxue [The Chinese University of Hong Kong], pp. 153-161.

Liu Fengzhu 刘凤翥 (1992): Lüelun qidanyu de yuxi guishu yu tedian 略论契丹语的语系归属 与特点 [A brief discussion on the genetic position and special features of the Khitan language]. Dalu zazhi 大陆杂志 Vol. 84, No. 5, pp. 19-26.

Liu Fengzhu 刘凤翥 (1993a): Qidan xiaozi jiedu sitan 契丹小字解读四探 [The Khitan Small Script: a fourth investigation]. In: Chen Jiexian 陈捷先 (ed.): Proceedings of the 35th Permanent International Altaistic Conference 第三十五届世界阿尔泰学会会议纪录 $D i$ Sanshiwujie Shijie Aertai Xuehui Huiyi Jilu (September 12-17, 1992, Taipei). Taipei, National Taiwan University, pp. 543-568.

Liu Fengzhu 刘凤翥 (1993b): Ruogan qidan dazi de jiedu ji qita 若干契丹字的解读及其它 [The decipherment of some Khitan Large Script characters and other matters]. Hanxue yanjiu 汉学研究 Vol. 11, No. 1, pp. 383-398. 
Liu Fengzhu 刘凤翥 (1996): Qidan dazi zhong ruogan guanming he diming zhi jiedu 契丹字中若 干官名和地名之解读 [The decipherment of some official titles and place names in the Khitan Large Script]. Minzu yuwen 民族语文 No. 4, pp. 37-44.

Liu Fengzhu 刘凤翥 (1998): Qidan dazi liushi nian zhi yanjiu 契丹大字六十年之研究 [Sixty years of research on the Khitan Large Script]. Zhongguo wenhua yanjiusuo xuebao 中国文化研 究所学报 No. 7, pp. 313-338.

Liu Fengzhu (1999): Seventy Years of Khitan Small Script Studies. In: Janhunen, Juha-Rybatzki, Volker (eds): Writing in the Altaic World. Helsinki, Finnish Oriental Society (Studia Orientalia 87$)$, pp. $159-169$.

Liu Fengzhu 刘凤翥 (2001): Zuijin 20 nian lai de qidan wenzi yanjiu gaikuang 最近20年来的契丹 文字研究概况 [A survey of research on the Khitan scripts during the last 20 years]. Yenching Journal of Chinese Studies (New Series) Vol. 11, pp. 205-246.

Liu Fengzhu 刘凤翥 (2002): Qidan xiaozi《Han Gaoshi muzhi» kaoshi 契丹小字〈韩高十墓 志〉考释 [A study of the epitaph of Han Gaoshi in the Khitan Small Script]. In: Yifenji: Zhang Zhenglang xiansheng jiushi huadan jinian wenji 揖芬集〈张政烺先生九十华诞纪 念文集〉 [Festschrift for Professor Zhang Zhenglang]. Beijing, Shehui Kexue Wenxian chubanshe, pp. 517-522.

Liu Fengzhu 刘凤翥 (2003): Jiedu qidan wenzi yu shenhua Liaoshi yanjiu 解读契丹文字与深化 辽史研究 [Deciphering the Khitan script and deepening the research on the history of the Liao dynasty]. Shixue huikan 史学汇刊 Vol. 18, pp. 187-201.

Liu Fengzhu 刘凤翥 (2004): Cong qidan wenzi de jiedu shuo «Dong Dan» guohao 从契丹字的解 读说〈东丹〉国号 [Explaining the dynasty name of «Dong Dan» on the basis of the decipherment of the Khitan script]. Dongbei Shi yanjiu 东北史研究 No. 1, pp. 41-42.

Liu Fengzhu 刘凤翥 (2005a): Qidan xiaozi «Xiao Temei / Kuoge Fuma Dier Furen Han Shi muzhiming》kaoshi 契丹小字〈萧特每・阔哥驸马第二夫人韩氏墓志铭〉考释 [A study of the epitaph of Mme. Han, the Second Wife of the Imperial Son-in-Law Xiao Temei in the Khitan Small Script]. In: Jin Kuo 金适 et al. (eds): Jin Qicong xiansheng shishi zhounian jinian wenji 金启孮先生逝世周年纪念文集 [Volume in memory of Professor Jin Jicong]. Kyoto, Nippon Toua Rekishi Bunka Kenkyuukai 日本東亞歷史文化研究會, pp. 191-197.

Liu Fengzhu 刘凤㯃 (2005b): Bianfang Qidan wenzi hua tabei 遍访契丹文字话拓碑 [Surveying Khitan Script monuments and discussing the methods of making rubbings]. Beijing, Huayi chubanshe.

Liu Fengzhu 刘凤翥 (2011a): Qidan xiaozi “Xiao Dilu muzhiming” he "Yelü Lianning muzhiming” jun wei yanpin 契丹小字《萧敌鲁墓志铭》和《耶律廉宁墓志铭》均为赝品 [The Khitan Small Script Xiao Dilu epitaph and Yelü Lianning epitaph are fakes]. Zhongguo shehui kexuebao 中国社会科学报 2011.05.19/5, pp. 1-2.

Liu Fengzhu 刘凤翥 (2011b): Zai lun “Xiao Dilu muzhiming” wei yan pin shuo 再论《萧敌鲁墓 志铭》为赝品说 [Once again on the fakeness of the Xiao Dilu epitaph]. Zhongguo shehui kexuebao 中国社会科学报 2011.06.16/5, pp. 1-6.

Liu Fengzhu 刘凤翥 (2011c): Zai lun “Yelü Lianning muzhiming” wei yan pin shuo 再论《耶 律廉宁墓志》为赝品 [Once again on the fakeness of Yelü Lianning epitaph]. Zhongguo shehui kexuebao 中国社会科学报 2011.11.10/5, pp. 1-2.

Liu Fengzhu 刘凤翥 (2014): Qidan xiaozi <Gu Yelü shi mingshi> kaoshi 契丹小字<故耶律氏铭 石>考释 [Philological examination of the Gu Yelü shi inscription in Khitan Small Script]. Chifeng xueyuan xuebao (Hanwen zhexue shehui kexueban) 赤峰学院学报 (汉文哲学社会 科学版) No. 35, pp. 1-7.

Liu Fengzhu 刘凤翥-Cong Yanshuang 从艳双-Yu Zhixin 于志新-Narangua 娜仁高娃 (2006): Qidan xiaozi «Yelü Cite / Wuliben muzhiming» kaoshi 契丹小字〈耶律慈特•元里本墓 
志铭〉考释 [A study of the epitaph of Yelü Cite / Wuliben in the Khitan Small Script]. Yanjing xuebao 燕京学报 No. 20, pp. 255-277.

Liu Fengzhu 刘凤翥-Dong Xinlin 董新林 (2007): Qidan xiaozi «Salan/Shilu Taishi muzhibei» kaoshi 契丹小字〈撒懒・室鲁太师墓志碑〉考释 [A study of the epitaph of Salan/Shilu Taishi in the Khitan Small Script]. Kaogu 考古 No. 5, pp. 69-73.

Liu Fengzhu 刘凤翥-Qinggele 清格勒 (2003): ‘Qidan xiaozi «Song Wei Guo Fei muzhiming» he 《Yelü Hongyong muzhiming» kaoshi’ 契丹小字〈宋魏国妃墓志铭〉和〈耶律弘用墓志 铭〉考释 [A study of the epitaph of the Late Imperial Consort of the States of Song and Wei and the epitaph of Yelü Hongyong in the Khitan Small Script]. Wenshi 文史 No. 4,pp. 194-208.

Liu Fengzhu 刘凤翥-Tang Cailan 唐彩兰 (2003): Liao “Xiao Xingyan muzhi” he "Yongningjun gongzhu muzhi” kaoshi 辽《萧兴言墓志》和《永宁郡公主墓志》考释 [A study of the epitaph of Xiao Xingyan and the epitaph of the Princess of Yongning prefecture]. Yanjing Journal of Chinese Studies New Number 14, pp. 71-93.

Liu Fengzhu 刘凤翥-Tang Cailan 唐彩兰-Gaowa 高娃 (2004): Liaodai Xiao Wuluben deng sanren de muzhi-ming kaoshi 辽代萧乌卢本等三人的墓志铭考释 [A study of the epitaph of Xiao Wuluben and two others of the Liao period]. Wenshi 文史 No. 2, pp. 99-118.

Liu Fengzhu 刘凤翥-Tang Cailan 唐彩兰-Gaowa 高娃 - Li Jiankui 李建奎 (2006): Liaodai “Yelü Longyou muzhiming” he “Yelü Gui muzhiming” kaoshi 辽代〈耶律隆佑墓志铭〉和〈耶 律贵墓志铭〉考释 [A study of the epitaph of Yelü Longyou and the epitaph of Yelü Gui of the Liao period]. Wenshi 文史 No. 4, pp. 116-142.

Liu Fengzhu 刘凤翥-Tang Cailan 唐彩兰-Qinggele 清格勒 (2009): Liao Shangjing Diqu Chutu de Liaodai Beike Huiji 辽上京地区出土的辽代碑刻汇辑 [A collection of inscriptions on steles excavated from the supreme capital of the Liao Dynasty]. Beijing, Shehui kexue wenxian chubanshe.

Liu Fengzhu 刘凤翥-Yu Baolin 于宝林 (1977): Qidan xiaozi “Xu Wang muzhi” kaoshi 契丹 小字〈许王墓志〉考释 [A study of the epitaph of Prince Xu in the Khitan Small Script]. Wenwu ziliao congkan 文物资料丛刊 No. 1, pp. 88-104.

Liu Fengzhu 刘凤翥-Yu Baolin 于宝林 (1981a): Qidan xiaozi “Xiao Zhonggong muzhi” kaoshi 契丹小字〈萧仲恭墓志〉考释 [A study of the epitaph of Xiao Zhonggong in the Khitan Small Script]. Minzu yanjiu 民族研究 No. 2, pp. 35-39.

Liu Fengzhu 刘凤翥-Yu Baolin 于宝林 (1981b): “Gu Yelü Shi Mingshi” bawei〈故耶律氏铭 石〉咙尾 [Comments on the epitaph of the Late Mme. Yelü]. Wenwu ziliao congkan 文物 资料从刊 No. 5, pp. 175-179.

Liu Fengzhu 刘凤翥-Zhou Hongshan 周洪山-Zhao Jie 赵杰-Zhu Zhimin 朱志民 (1995): Qidan xiaozi jiedu wu tan 契丹小字解读五探其他 [The decipherment of the Kitan Small Script - fifth investigation]. Hanxue yanjiu 汉学研究 Vol. 13, No. 2, pp. 313-348.

Liu Pujiang 刘浦江 (1999): Nei Menggu Aohan Qi chutu de Jindai Qidan xiaozi muzhi canshi kaoshi 内蒙古敖汉旗出土的金代契丹小字墓志残石考释 [A study of the broken epitaph of the Jin period excavated in Aohan Banner, Inner Mongolia]. Kaogu 考古 No. 5, pp. 85-89.

Liu Pujiang 刘浦江 (2004): Ershi Shiji Liao Jin Shi Lunzhu Mulu 二十世纪辽金史论著目绿 [A catalogue of research on Liao and Jin history in the 20th century]. Shanghai, Shanghai cishu chubanshe.

Liu Pujiang 刘浦江 (2008): Song mo zhi jian: Liao Jin qidan nüzhen shi yanjiu 松漠之间. 辽金契 丹女真史研究 [Between forest and desert: Research on the history of the Khitan and Jurchen of the Liao and Jin]. Beijing, Zhonghua shuju.

Liu Pujiang 刘浦江-Kang Peng 康鹏 (2005): Qidan ming, zi chutan: Wenhua renleixue shiyexia de fu zi lianmingzhi 契丹名, 字初探. 文化人类学视野下的父子连名制 [A preliminary 
study of Khitan names: The linkage between the names of father and son from the point of view of cultural anthropology]. Wenshi 文史 No. 3, pp. 209-256.

Liu Pujiang 刘浦江 - Kang Peng 康鹏 (2014): Qidan xiaozi cihui suoyin 契丹小字词汇索引 [An index of the Khitan Small Script lexicon]. Beijing, Zhonghua shuju.

Liu Shujuan 刘淑娟 (1998): Liaodai tongjing yanjiu 辽代铜镜研究 [Research on the bronze mirrors of the Liao period]. Shenyang, Shenyang chubanshe.

Lu Baolin 鲁宝林-Xin Fa 辛发-Wu Peng 吴鹏 (1993): Beizhen Liao Yelü Zongjiao mu 北镇辽 耶律宗教墓 [The tomb of Yelü Zongjiao of the Liao at Beizhen]. Liaohai wenwu xuekan 辽海文物学刊 No. 2, pp. 36-42.

Lu Yinghong 卢迎红-Zhou Feng 周峰 (2000): Qidan xiaozi «Yelü Dilie muzhiming» kaoshi 契丹小字〈耶律迪烈墓志铭〉考释 [A study of the epitaph of Yelü Dilie in the Khitan Small Script]. Minzu yuwen 民族语文 No. 1, pp. 43-52.

Lü Zhenkui 吕振奎 (1995): Haitangshan qidan xiaozi muzhi canshi bushi 海棠山契丹小字慕志残 石补释 [Corrections concerning the Khitan Small Script broken epitaph of Haitangshan]. Minzu yuwen 民族语文 No. 4, pp. 51-53.

Lü Zhenkui 吕振奎-Yuan Haibo 袁海波 (1992): Liaoning Fuxin Haitangshan faxian Qidan xiaozi zaoxiangbei 辽宁阜新海棠山发现契丹小字造像碑 [The stele with a Khitan Small Script inscription discovered at Haitangshan, Fuxin, Liaoning]. Kaogu 考古 No. 8, pp. 766-768.

Luo Fucheng 羅福成 (1933): Liao Xuanyi Huanghou aice shiwen 遼宣懿皇后哀册釋文 [An explanation of the epitaph of Empress Xuanyi of the Liao]. Manshuu Gakuhou 滿洲學報 No. 2, pp. $1-7$.

Meng Sen 孟森 (1932): Liaobei jiuzhong fubawei. 遼碑九種附跋尾 [Additional comments on nine kinds of Liao steles]. Beijing Daxue guoxue jikan 北京大學國學季刊 Vol. 3, No. 3, pp. 397-419.

Mullie, Jos[eph] (1922): Les anciennes villes de l'empire des grands Leao 大遼 au royaume mongol de Bārin. T'oung Pao Vol. 21. pp. 105-231.

Mullie, Joseph (1933): Les sépultures de K'ing des Leao 遼慶陵. T'oung Pao Vol. 30, pp. 1-25.

Nei Menggu zizhiqu wenwu kaogu yanjiusuo 内蒙古自治区文物考古研究所-Zhelimu meng bowuguan 哲里木盟博物馆 (1993): Liao Chen guo gongzhu mu 辽陈国公主墓 [The tomb of the Liao Princess of the State of Chen]. Beijing, Wenwu chubanshe.

Nie Hongyin 聂鸿 (1999): Qidan dazi jiedu qianyi 契丹大字解读浅议 [A brief discussion on the decipherment of the Khitan Large Script]. Minzu yuwen 民族语文 No. 4, pp. 51-57.

Nie Hongyin 聂鸿音 - Sun Bojun 孙伯君 (2010): Zhongguo duowenzi shidai de lishi wenxian yanjiu 中国多文字时代的历史文献研究 [Research on historical records in the periods of multiple scripts]. Zhongguo she hui ke xue yuan zhong dian xue ke. Min zu xue ren lei xue xi lie. 中 国社会科学院重点学科·民族学人类学系列 [Core subjects of the Academy of Social Sciences of China. Ethnology and anthropology series]. Beijing, Shehui kexue wenxian chubanshe.

Nishida Tatsuo [Xitian Longxiong] 西田龍雄 (1992): Guanyu qidan xiaozi yanjiu zhong de jibenxing wenti 矢于契丹字研究中的基本性问题 [About some fundamental issues in the research on the Khitan Small Script]. Minzu yuwen 民族语文 No. 2, pp. 10-13.

Qidan wenzi yanjiu xiaozu 契丹字研究组 (1977): Guanyu qidan xiaozi yanjiu 矢于契丹小字研究 [About research on the Khitan Small Script]. Nei Menggu daxue xuebao (Zhexue shehui kexueban) 内蒙古大学学报 (哲学社会科学版) No. 4, pp. 1-97.

Qidan wenzi yanjiu xiaozu 契丹文字研究小组 (1978): Qidan dazi ziliao huiji 契丹大字资料汇辑 [Collection of materials on the Khitan Large Script]. [s.l.] 
Qidan wenzi yanjiu xiaozu 契丹文字研究小组 (1979): Qidan xiaozi yanjiu fangfa jianlun 契丹小 字研究方法简论 [The methods of research on the Khitan Small Script]. [s.1.] Nei Menggu daxue menggu yuwen yanjiushi.

Qidan wenzi yanjiu xiaozu 契丹文字研究小组 (1985): Qidan xiaozi yanjiu 契丹小字研究 [Research on the Khitan Small Script]. Beijing, Zhongguo shehui kexue chubanshe.

Qimudedaoerji 齐木德道尔吉 (2002): Cong Yuan Mengguyu dao qidanyu 从原蒙古语到契丹语 [From Proto-Mongolic to Khitan]. Zhongyang Minzu Daxue xuebao 中央民族大学学报 Vol. 29, No. 3, pp. 132-138.

(Qinggeertai) Chingeltei (1987): Kitan üsüg-ün sudulyan-u sin-e bayidal [The new situation in the

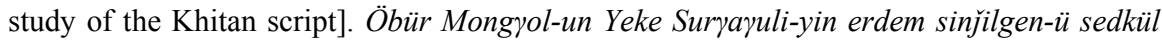
No. 3, pp. 106-132.

Qinggeertai 清格尔泰 (1997): Qidanyu shuci ji qidan xiaozipin dufa 契丹语数词及契丹小字拼 读法 [The Khitan numerals and the reading of the Khitan Small Script graphic combinations]. Nei Menggu daxue xuebao (Zhexue shehui kexueban) 内蒙古大学学报 (哲学社会 科学版) No. 4, pp. 1-9.

(Qinggeertai) Chingeltei (2002a): On the Problems of Reading Kitan Characters. $A O H$ Vol. 55, pp. 99-114.

Qinggeertai 清格尔泰 (2002b): Qidan xiaozi shidu wenti 契丹小字释读问题 [Problems of the decipherment of the Khitan Small Script]. Tokyo, Tokyo University of Foreign Studies, Research Institute for Languages and Cultures of Asia and Africa.

Qinggeertai 清格尔泰 (2002c): Guanyu qidan xiaozi “Da qidan guo" de shidu wenti 矢于契丹 小字〈大契丹国〉的释读问题 [The question concerning the decipherment of the term "Great Khitan State" in the Khitan Small Script]. Nei Menggu daxue xuebao (Zhexue shehui kexueban) 内蒙古大学学报 (哲学社会科学版) Vol. 34, No. 32, pp. 9-14.

Qinggeertai 清格尔泰 - Wu Yingzhe 吴英喆 - Jiruhe 吉如何 (forthcoming): Qidan xiaozi zai yanjiu 契丹小字再研究 [Renewed research on the Khitan Small Script].

Róna-Tas, András (1999): Honfoglalás és népalakulás a középkori Eurázsiában. Kitajok, avarok, magyarok [Conquest and formation of nations in Mediaeval Eurasia. Khitans, Avars, Hungarians]. Székfoglalók a Magyar Tudományos Akadémián. Budapest, Magyar Tudományos Akadémia.

Róna-Tas, András (2004): A Khitan Word for 'Marmot'. AOH Vol. 57, pp. 27-29.

Róna-Tas, András (2016a): Khitan Studies I. The Graphs of the Khitan Small Script 1. General Remarks, Dotted Graphs, Numerals. $A O H$ Vol. 69, pp. 117-138.

Róna-Tas, András (2016b): Remarks on the Ethnonym Khitan. Turkic Languages Vol. 20, No. 2, pp. 157-169.

Shi Jinmin 石金民-Yu Zemin 于泽民 (2001): Qidan xiaozi «Yelü Nu muzhiming» kaoshi 契丹小 字〈耶律奴墓志铭〉考释 [A study of the epitaph of Yelü Nu in the Khitan Small Script]. Minzu yuwen 民族语文 No. 2, pp. 61-68.

Shimunek, Andrew (2007): Towards a Reconstruction of the Kitan Language, with Notes on Northern Late Middle Chinese Phonology. Unpublished manuscript, MA Thesis, Indiana University.

Sun Bojun 孙伯君 (2010): Qidan xiaozi jiedu xintan 《契丹小字解读新探》[A new attempt at reading the Khitan Small Script]. Minzu yuwen 民族语文 No. 5, pp. 56-64.

Sun Bojun 孙伯君-Nie Hongyin 聂鸿 (2008): Qidanyu yanjiu 契丹语研究 [Research on the Khitan language]. Beijing, Zhongguo shehui kexueyuan wenku wenxue yuyan yanjiu xilie.

Tang Cailan 唐彩兰-Liu Fengzhu 刘凤翥-Kang Lijun 康立君 (2002): Qidan xiaozi “Han Dilie muzhiming” kaoshi 契丹小字〈韩敌烈墓志铭〉考释 [A study of the epitaph of Han Dilie in the Khitan Small Script]. Minzu yuwen 民族语文 No. 6, pp. 29-37. 
Tang Wei Lan 唐彩兰 (ed.) (2005): Liao shangjing wenwu xieying 辽上京文物撷英 [Selected cultural relics of the Liao period]. Huhehaote, Yuanfang chubanshe.

Toyoda Gorō 豐田五郎 (1964): An Analysis of the Major Ch'i-tan Characters. Memoirs of the Research Department of the Toyo Bunko Vol. 23, pp. 119-135.

Toyoda Gorō 丰田五郎 [Fengtian Wulang] (1991): Guanyu qidan xiaozi de jidian tansuo 全于契 丹小字的几点探索 [About some investigations into the Khitan Small Script]. Nei Menggu daxue xuebao (Zhexue shehui kexueban) 内蒙古大学学报(哲学社会科学版) No. 3, pp. $105-114$.

Toyoda Gorō 丰田五郎 [Fengtian Wulang] (1992): Guanyu qidan xiaozi de fangwei he yixie shuci 矢于契丹小字的方位和一些数词 [About the directions and some numerals in the Khitan Small Script]. In: Liu Fengzhu 刘凤翥-Lu Xun 卢勋-Hua Zugen 华祖根 (eds): Zhongguo minzushi yanjiu 中国民族史研究 [Research on the ethnic history of China]. Vol. 4. Beijing, Gaige chubanshe, pp. 71-81.

Toyoda Gorō 丰田五郎 [Fengtian Wulang] (1995): Jiedu qidan dazi de xiansuo 解读契丹大字 的线索 [A clue to the decipherment of the Khitan Large Script]. In: Su He 苏赫-Tian Guanglin 田广林-Xue Zhiqiang 薛志强 (eds): Zhongguo beifang gudai wenhua guoji xueshu taolunhui lunwenji 中国北方古代文化国际学术讨论会论文集 [Collection of papers from the International Conference on Ancient Cultures in Northern China]. Beijing, Zhongguo wenshi chubanshe, pp. 298-313.

Toyoda Gorō 丰田五郎 [Fengtian Wulang] (1998): Qidan xiaozi dui siji de chenghu 契丹字对四 季的称呼 [The names of the four seasons in the Khitan Small Script]. Minzu yuwen 民族 语文 No. 1, pp. 78-81.

Vovin, Alexander (2011): A Modest Proposal on the Decipherment of the Khitan-Jurchen Bilingual Text of 1134 (the Langjun Inscription). In: Knüppel, Michael-van Tongerloo, Aloïs (eds): Life and Afterlife \& Apocalyptic Concepts in the Altaic World. Proceedings of the 43rd Annual Meeting of the Permanent International Altaistic Conference (PIAC) - Château Pietersheim, Belgium, September, 3-8, 2000. Wiesbaden, Harrassowitz (Tunguso-Sibirica 31), pp. $123-130$.

Wan Xiongfei 万雄飞-Han Shiming 韩世明-Liu Fengzhu 刘凤翥 (2008): Qidan xiaozi “Liang Guo Wang muzhiming” kaoshi 契丹小字〈梁国王墓志铭〉考释 [A study of the epitaph of the Prince of the State of Liang in the Khitan Small Script]. Yanjing xuebao 燕京学报 Vol. 25, pp. 123-159.

Wang Ding (2004): Ch 3586 - ein khitanisches Fragment mit uighurischen Glossen in der Berliner Turfansammlung. In: Durkin-Meistererns, Desmond-Raschman, Simone-Christiane-Wilken, Jens - Yaldi, Marianne-Zieme, Peter (eds): Turfan Revisited: The First Century of Research into the Arts and Cultures of the Silk Road. Berlin, Dietrich Reimer Verlag, pp. $371-379,465$.

Wang Hongli 王弘力 (1986): Qidan xiaozi muzhi yanjiu 契丹小字墓志研究 [Research on epitaphs in the Khitan Small Script]. Minzu yuwen 民族语文 No. 4, pp. 56-70.

Wang Jingru 王靜如 (1933): Liao Daozong ji Xuanyi Huanghou qidan guozi aice chushi 遼道宗及 宣懿皇后契丹國字哀册初釋 [A preliminary explanation of the eulogies for Daozong and Empress Xuanyi in the Khitan national script]. Lishi yuyan yanjiusuo jikan 歷史語言研究 所集刊 No. 3, pp. 467-478.

Wang Weixiang 王未想 (1999): Qidan xiaozi «Zezhou Cishi muzhi» canshi kaoshi 契丹小字〈泽 州刺史墓志 $>$ 残石考释 [A study of the Khitan Small Script broken epitaph of the prefect of Zezhou]. Minzu yuwen 民族语文 No. 2, pp. 78-81.

Wu Yingzhe 吴英喆 (2003): Kitan üsüg kiged Kitan üsüg-ün sudulul [The Khitan script and its research]. Mongyol-un sudulul No. 2, pp. 51-54. 
Wu Yingzhe 吴英喆 (2004): Guanyu qidan xiaozi zhong de «Da Jin Guo» de 《Jin» 矢于契丹小字 中的 《大金国》 的 《金》 [On the character "Jin" in the name of the "Great Jin Empire" in the Khitan Small Script]. Zhongyang minzu daxue xuebao (Zhexue shehui kexueban) 中央民族 大学学报 (哲学社会科学版) No. 6, pp. 113-116.

Wu Yingzhe 吴英吉 (2005): Qidan xiaozi 《xing» de yufa fanchou chutan 契丹小字“性”的语法范 畴初探 [Preliminary research on the grammatical category of gender in the Khitan Small Script]. Nei Menggu daxue xuebao (Zhexue shehui kexueban) 内蒙古大学学报(哲学社会 科学版) No. 3, pp. 25-28.

Wu Yingzhe 吴英吉 (2007a): Qidanyu jingci yufa fanchou yanjiu 契丹语静词语法范畴研究 [Research on the grammatical categories of the noun in the Khitan language]. Huhehaote, Nei Menggu daxue chubanshe.

Wu Yingzhe 吴英喆 (2007b): Kittan koaza kenkyū gaikyō 契丹小字研究概況 [An outline of research on the Khitan Small Script]. Kotonoha 言の葉 Vol. 52, pp. 1-7.

Wu Yingzhe 吴英喆 (2007c): Kittan Shouji kenkyuu no genzai 契丹小字研究の現在 [Present state of Khitan Small Script studies]. Ryuukoku Shidan 龍谷史壇 Vol. 127, pp. 1-17.

Wu Yingzhe 吴英吉 (2007d): Kitan bay-a üsüg-ün “örlüge-yin sigüderi söni-yin sara” gekü kelelgeyin tayilburi [An explanation of the expression «Morning dew, Night moon» in the Khitan

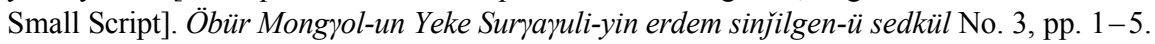

Wu Yingzhe 吴英喆 (2007e): Qidan xiaozi zhong de Hanyu rusheng yunwei de henji 契丹字中的 汉语声韵尾的痕迹 [Traces of Chinese rhymes with the entering tone in the Khitan Script]. Hanzi wenhua 汉字文化 No. 3, pp. 26-29.

Wu Yingzhe 吴英喆 (2007f): Qidan xiaozi zhong de 《yuanyin fujiafa» 契丹小字中的 “元音附加 法” [The "principle of vowel attachment" in the Khitan Small Script]. Minzu yuwen 民族 语文 No. 4, pp. 40-51.

Wu Yingzhe 吴英喆 (2011a): Qidan xiaozi “Dielabu” kaoshi 契丹小字“迭剌部”考释 [A textual study on the tribal name Diela in the Khitan Small Script]. Minzu yuwen 民族语文 No. 5, pp. $72-77$.

Wu Yingzhe 吴英喆 (2011b): Qidan xiaozi “Xiao Dilu muzhiming” ji “Yelü Xiangwen muzhi” jue fei yanpin 契丹小字《萧敌鲁墓志铭》及《耶律详稳墓志》绝非㕍品 [The Khitan Small Script Xiao Dilu epitaph and Yelü Lianning epitaph are not at all fakes]. Zhongguo shehui kexuebao 中国社会科学报 2011.12.08/005, pp. 1-3.

Wu Yingzhe 吴英喆 (2012a): Kittan shoji shinhakken shiryo shakudoku mondai 契丹小字新発見 資料釈読問題 [Interpretation problems of the newly-discovered Khitan Small Script materials]. Tokyo, Research Institute for Languages and Cultures of Asia and Africa (ILCAA).

Wu Yingzhe 吴英喆 (2012b): Qidan wen diangu < rensheng qishi gu lai xi > 契丹文典故 <人生七 十古来稀> [A study on a literary quotation in Khitan Script: “A man seldom lives to be seventy years old”]. Zhongyang Minzu Daxue xuebao (Zhexue shehui kexueban) 中央民族大 学学报 (哲学社会科学版) No. 6, pp. 106-109.

Wu Yingzhe 吴英喆 - Baoyindeligen 宝音德力根-Jiruhe 吉如何 (2009): Guanyu xinjin faxian de jijian qidanwen muzhi ji yiwang fabiao de qidanwen ziliao 矢于新近发现的几件契丹文墓 志及以往发表的契丹文资料 [About several recently discovered Khitan epitaphs and previously published Khitan materials]. Altai Hakpo No. 19, pp. 139-154.

Wu Yingzhe - Janhunen, Juha (2010): New Materials on the Khitan Small Script. A Critical Edition of Xiao Dilu and Yelü Xiangwen. Folkestone, Global Oriental [Corpus Scriptorum Chitanorum I] (Languages of Asia 9).

Wu Yingzhe 吴英吉 - Tang Jun 唐均 (2013): 8th Issue of Acta Linguistica et Litteraturaria Sinica Occidentalia (Huaxi yuwen xuekan 华西语文学刊). Chengdu, Xinan jiaotong daxue waiguoyu xueyuan. 
Yan Wanzhang 阎万章 (1993): Qidan xiaozi “Yelü Zongjiao muzhiming kaoshi” 契丹小字《耶律 宗教墓志铭》考释 [A study of the "Epitaph of Yelü Zongjiao" in the Kitan Small Script]. Liaohai wenwu xuekan 辽海文物学刊 No. 2, pp. 112-117. Reprinted in Chen-Bao (2005, pp. 646-656).

Yang Jie 杨杰 (2003): Wurigentala Liaomu chutu de qidan xiaozi muzhiming zaikao 乌日根塔 拉辽墓出土的契丹小字墓志铭再考 [A re-examination of the epitaph in the Khitan Small Script excavated from the Liao tomb at Wurigentala]. Xibei minzu yanjiu 西北民族研究 No. 4 , pp. $68-70$.

Yirigui 伊日贵 (2011): Qidan xiaozi “Yelü fubushu muzhiming” yu qidan dazi "Yelü Qi muzhiming” bijiao yanjiu 契丹小字 < 耶律副部署墓志铭 > 与契丹大字 < 耶律祺墓志铭 $>$ 比 较研究 [A comparative study of the Khitan Small Script epitaph of Deputy Administrator Yelü and the Khitan Large Script epitaph of Yelü Qi]. MA Thesis, Inner Mongolia University.

Yu Baolin 于宝林 (1998): Qidian gudaishi lungao 契丹古代史论稿 [A draft of Khitan ancient history]. Hefei, Huangshan shushe.

Yuan Haibo 袁海波 - Liu Fengzhu 刘凤翥 (2005): Qidan xiaozi «Xiao Dashan he Yongqing Gongzhu muzhiming》kaoshi 契丹小字＜萧大山和永清公主墓志铭> 考释 [A study of the epitaph of Xiao Dashan and Princess Yongqing in the Khitan Small Script]. Wenshi 文史 No. 1, pp. 207-221.

Zajcev, Vjačeslav P. (2011): Rukopisnaja kniga bol'šogo kidan'skogo pis'ma iz kollekcii Instituta Vostočnyx Rukopisej RAN. Pis'mennye pamjatniki Vostoka Vol. 15, pp. 130-150.

Zhao Feng 趙豐 (2004): Liao Textile \& Costumes 遼代絲綢 Liaodai sichou. Hong Kong, Muwen Tang 沐文堂.

Zhao Zhiwei 赵志伟-Bao Ruijun 包瑞军 (2001): Qidan xiaozi «Yelü Zhixian muzhiming» kaoshi 契丹小字〈耶律智先墓志铭〉考释 [A study of the epitaph of Yelü Zhixian in the Khitan Small Script]. Minzu yuwen 民族语文 No. 3, pp. 34-41.

Zhaowuda Meng Wenwu Gongzuozhan 昭乌达盟文物工作站-Wengniute Qi Wenhuaguan 翁牛 特旗文化馆 (1981): Nei Menggu Shanzuizi «Gu Yelü Shi» mu fajue baogao 内蒙古山嘴 子〈故耶律氏〉墓发掘报告 [A report on the excavation of the tomb of the Late Mme. Yelü in Inner Mongolia]. Wenwu ziliao congkan 文物资料丛刊 No. 5, pp. 167-171.

Zheng Shaozong 郑绍宗 (1973): Xinglong xian Zimulinzi faxian de qidanwen muzhiming 兴隆 县梓木林子发现的契丹文墓志铭 [A Khitan epitaph discovered at Zimulinzi, Xinglong County]. Kaogu 考古 No. 5, pp. 300-399.

Zheng Xiaoguang 郑晓光 (2002): Qidan xiaozi «Yelü Yongning Langjun muzhiming» kaoshi 契丹小字〈耶律永宁郎君墓志铭〉考释 [A study of the epitaph of Prince Yelü Yongning in the Khitan Small Script]. Minzu yuwen 民族语文 No. 2, pp. 63-69.

Zhongguo Lishi Bowuguan 中国历史博物馆-Nei Menggu Zizhiqu wenhuating 内蒙古自治区文 化厅 (2002): Qidan Wangchao: Nei Menggu Liaodai wenwu jingpin 契丹王朝. 内蒙古辽 代文物精品 [The Khitan Dynasty: Masterpieces of Liao period relics from Inner Mongolia]. Beijing, Zhongguo Zangxue chubanshe.

Zhu Tianshu 朱天舒 (1998): Liao dai jinyinqi 辽代金银器 [Gold and silver objects of the Liao period]. Beijing, Wenwu chubanshe.

Zhu Zhimin 朱志民 (1995): Nei Menggu Aohan qi Laohugou Jindai Bozhou Fangyushi mu 内蒙 古敖汉旗老虎沟金代博州防御使墓 [The tomb of the Defense Commissioner of Bozhou of the Jin period at Laohugou, Aohan Banner, Inner Mongolia]. Kaogu 考古 No. 9, pp. $802-807$. 